ano 15 - n. 61 I julho/setembro - 2015

Belo Horizonte I p. 1-270 I ISSN 1516-3210

A\&C - R. de Dir. Administrativo \& Constitucional

Revista de Direito ADMINISTRATIVO \& CONSTITUCIONAL

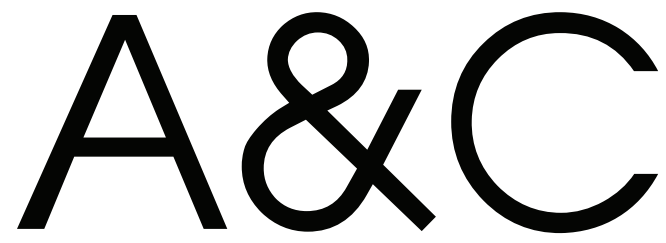




\section{A\&C - REVISTA DE DIREITO ADMINISTRATIVO \& CONSTITUCIONAL}

IPDA

Instituto Paranaense

de Direito Administrativo
ROMEU DEUPE

BACELLAR

๑) 2015 Editora Fórum Ltda.

Todos os direitos reservados. É proibida a reprodução total ou parcial, de qualquer forma ou por qualquer meio eletrônico ou mecânico, inclusive através de processos xerográficos, de fotocópias ou de gravação, sem permissão por escrito do possuidor dos direitos de cópias (Lei no 9.610, de 19.02.1998).

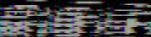

Luís Cláudio Rodrigues Ferreira

Presidente e Editor

Av. Afonso Pena, 2770 - 16ํandar - Funcionários - CEP 30130-007 - Belo Horizonte/MG - Brasil - Tel.: 08007043737 www.editoraforum.com.br / E-mail: editoraforum@editoraforum.com.br

Impressa no Brasil / Printed in Brazil / Distribuída em todo o Território Nacional

Os conceitos e opiniões expressas nos trabalhos assinados são de responsabilidade exclusiva de seus autores.

A246 A\&C : Revista de Direito Administrativo \&
Constitucional. - ano 3, n. 11, jan./mar.
2003)- . - Belo Horizonte: Fórum, 2003-
Trimestral
ISSN: 1516-3210
Ano 1, n. 1, 1999 até ano 2, n. 10, 2002 publicada
pela Editora Juruá em Curitiba
$\begin{aligned} & \text { 1. Direito administrativo. 2. Direito constitucional. } \\ & \text { I. Fórum. } \\ & \text { CDD: } 342 \\ & \text { CDU: } 342.9\end{aligned}$

Supenvisão editorial: Leonardo Eustáquio Siqueira Araújo

Capa: Igor Jamur

Projeto gráfico: Walter Santos

\section{Periódico classificado no Estrato A1 do Sistema Qualis da CAPES - Área: Direito.}

Revista do Programa de Pós-graduação do Instituto de Direito Romeu Felipe Bacellar (Instituição de Pesquisa e Pós-Graduação), em convênio com o Instituto Paranaense de Direito Administrativo (entidade associativa de âmbito regional filiada ao Instituto Brasileiro de Direito Administrativo). A linha editorial da $A \& C$ - Revista de Direito Administrativo \& Constitucional segue as diretrizes do Programa de Pós-Graduação do Instituto de Direito Romeu Felipe Bacellar em convênio com o Instituto Paranaense de Direito Administrativo. Procura divulgar as pesquisas desenvolvidas na área de Direito Constitucional e de Direito Administrativo, com foco na questão da efetividade dos seus institutos não só no Brasil como no direito comparado, com ênfase na questão da interação e efetividade dos seus institutos, notadamente América Latina e países europeus de cultura latina.

A publicação é decidida com base em pareceres, respeitando-se o anonimato tanto do autor quanto dos pareceristas (sistema double-blind peer review).

Desde o primeiro número da Revista, $75 \%$ dos artigos publicados (por volume anual) são de autores vinculados a pelo menos cinco instituições distintas do Instituto de Direito Romeu Felipe Bacellar.

A partir do volume referente ao ano de 2008 , pelo menos $15 \%$ dos artigos publicados são de autores filiados a instituições estrangeiras.

Esta publicação está catalogada em:

- Ulrich's Periodicals Directory

- RVBI (Rede Virtual de Bibliotecas - Congresso Nacional)

- Library of Congress (Biblioteca do Congresso dos EUA)

A\&C - Revista de Direito Administrativo \& Constitucional realiza permuta com as seguintes publicações: - Revista da Faculdade de Direito, Universidade de São Paulo (USP), ISSN 0303-9838

- Rivista Diritto Pubblico Comparato ed Europeo, ISBN/EAN 978-88-348-9934-2 
Diretor-Geral

Romeu Felipe Bacellar Filho

Diretor Editorial

Paulo Roberto Ferreira Motta

Editores Acadêmicos Responsáveis

Daniel Wunder Hachem

Ana Cláudia Finger

Assessor Editorial

Felipe Klein Gussoli

\section{Conselho Editorial}

Adilson Abreu Dallari (PUC-SP) Juan Pablo Cajarville Peluffo (Universidad de La República - Uruguai) ardo Schier (Instituto Bacellar) Justo J. Reyna (Universidad Nacional del Litoral - Argentina)

Alice Gonzalez Borges (UFBA) Juarez Freitas (UFRGS)

Carlos Ari Sundfeld (FGV-SP) Luís Enrique Chase Plate (Universidad Nacional de Asunción - Paraguai)

Carlos Ayres Britto (UFSE) Marçal Justen Filho (UFPR)

Adriana da Costa Ricardo Schier (Instituto Bacellar)
Alice Gonzalez Borges (UFBA)

Marcelo Figueiredo (PUC-SP)

Márcio Cammarosano (PUC-SP)

Carlos Delpiazzo (Universidad de La República - Uruguai) Cármen Lúcia Antunes Rocha (PUC Minas) Célio Heitor Guimarães (Instituto Bacellar) Celso Antônio Bandeira de Mello (PUC-SP) Clèmerson Merlin Clève (UFPR) Clovis Beznos (PUC-SP) Edgar Chiuratto Guimarães (Instituto Bacellar) Maria Cristina Cesar de Oliveira (UFPA)

Nelson Figueiredo (UFG)

Odilon Borges Junior (UFES)

Pascual Caiella (Universidad de La Plata - Argentina)

Emerson Gabardo (UFPR)

Paulo Eduardo Garrido Modesto (UFBA)

Paulo Henrique Blasi (UFSC)

Enrique Silva Cimma (Universidad de Chile - Chile) Eros Roberto Grau (USP)

Irmgard Elena Lepenies (Universidad Nacional del Litoral - Argentina) de La Coruña - Espanha)

Pedro Paulo de Almeida Dutra (UFMG)

Regina Maria Macedo Nery Ferrari (UFPR)

Rogério Gesta Leal (UNISC)

Rolando Pantoja Bauzá (Universidad Nacional de Chile - Chile)

Sergio Ferraz (PUC-Rio)

Valmir Pontes Filho (UFCE)

José Eduardo Martins Cardoso (PUC-SP)

José Luís Said (Universidad de Buenos Aires - Argentina) José Mario Serrate Paz (Universidad de Santa Cruz - Bolívia)

Yara Stroppa (PUC-SP)

\section{Homenagem Especial}

Guillermo Andrés Muñoz (in memoriam) Jorge Luís Salomoni (in memoriam) Julio Rodolfo Comadira (in memoriam) Lúcia Valle Figueiredo (in memoriam)

Manoel de Oliveira Franco Sobrinho (in memoriam) Paulo Neves de Carvalho (in memoriam) 


\title{
The Case of 4G Technology in the Brazilian Telecommunication Law
}

\section{Felipe Tadeu Ribeiro Morettini}

Master's degree in Economic and Environmental Social Law at Pontifícia Universidade Católica do Paraná (Curitiba - PR). Expert's qualification in Administrative Law at Universidade Estadual de Londrina. Federal Attorney (Attorney General's Office). E-mail: <felipe_morettini@hotmail.com>.

\section{Emerson Gabardo}

Professor of Administrative Law at the Universidade Federal do Paraná - UFPR and Professor of Economic Law of the PhD in Law Program of the Pontificia Universidade Católica do Paraná - PUCPR (Curitiba - PR). PhD in Public Law at the Universidade Federal do Paraná. Post-doctorate (Visiting Scholar) in Public Comparative Law at the Fordham University School of Law. Executive Director of NINC - Núcleo de Investigações Constitucionais da Universidade Federal do Paraná (Constitutional Research Center - www.ninc.com.br). Coordinator of NUPED - Núcleo de Pesquisas em Políticas Públicas e Desenvolvimento Humano da PUCPR (Public Policies and Human Development Research Center). E-mail: <e.gab@uol.com.br>.

\begin{abstract}
The constant and fast evolution of the telecommunications industry has forced the necessity for insertion of mechanisms in its regulations in order to reach the objectives aimed at the development outlined by the Brazilian Federal Constitution. In this sense, a sectorial public policy was elaborated to increase universalization and competition. The government acquisition process for authorization for the operation of the technology called $4 G$ in Brazil, from them, sought, on the one hand, to expand the universalization through cross-subsidization embodied in the joint bidding of frequency bands in rural areas and on the other, increase competition through the mandatory waiver of existing authorizations in old technologies that will coexist with the new. To verify if such expedients can achieve the proposed goal, this paper, using the descriptive, inductive and interdisciplinary methods, establish, first, the current regulatory framework of the sector and technical aspects of new broadband, to later compare instruments used with similar Brazilian and international previous experiences. Finally, one comes to the conclusion that universalization can be achieved with such instruments, which does not occur with the competition.
\end{abstract}

Key words: Telecommunications. Universalization. Competition. Development. Company.

Summary: Introduction - I Current Broadband Scenario in the Brazilian Telecommunications Sector II Public Policy Requirements for the Sector at the Invitation to Tender - III Previous National Experience in the Search for Universal Access to 3G Technology and Several Points Regarding Competition - IV Some International Experiences - V The requirements of the Invitation to Tender and the Development issue VI Conclusion - References

\section{Introduction}

In June 2012, an auction was conducted by the Brazilian National Telecommunications Agency (Agência Nacional de Telecomunicações - ANATEL) 
to publically tender the licenses to use radio frequencies in the $450 \mathrm{MHz}$ and $2.5 \mathrm{GHz}$ sub-bands (the latter are known as $4 G$ technology), which included the possibility of granting the Fixed Switched Telephone Service for General Public Use (FSTS), the Personal Mobile Service (PMS) and Multimedia Communication Service (MCS).

Such licenses to exploit a public good represent a significant benefit for the telecommunications sector because they will facilitate a substantive increase in the exchange of data between service users. Therefore, questions have been raised regarding the contribution of this license-granting process to development, which is understood as changes in the economic and social structure ${ }^{1}$ and characterized as a process of institutionalizing economic democracy. ${ }^{2}$ Given the recent increase in demand for communications services by consumers, broadband presents an important opportunity to increase related infrastructure. The same phenomenon occurred in the USA. According to Degnan, McLaren and Tennant, the increase in consumer demand requires a corresponding increase in the number of mobile transmission sites because as a cellular telephone user travels from one area to another, the transmission of a telephone call is moved from one transmission location to the next. ${ }^{3}$ By increasing the demand, the transmission area increases, causing gaps between locations. To fill these gaps, providers of cellular services should construct additional sites to accommodate the increased demand without sacrificing the service quality, which requires an efficient regulation that encourages such behavior.

According to Salomão Filho, there are three principles of economic order that enable society to choose between options: the redistributive principle, the principle of dilution of the economic power centers and the cooperation principle. The primary goal of the Brazilian government is to promote development through the adoption of these principles. Thus, its intervention by guidance in the economic field becomes relevant, with a substantial contribution by regulation, either by authorizing the use of public property or through the exercise of police power. ${ }^{4}$

In this context, ANATEL's tender of radio frequency bands represents a case of regulation with developmental scope in search of the forced diffusion of economic knowledge. This diffusion occurs by the implementation of the redistributive principle (observed in determining the expansion of service to rural areas by the companies

\footnotetext{
NUSDEO, F. Curso de Economia - Introdução ao Direito econômico. 3. ed. São Paulo: Revista dos Tribunais, 2001. p. 349.

2 SALOMÃO FILHO, C. (Coord.). Regulação e desenvolvimento. São Paulo: Malheiros, 2002. p. 32.

3 DEGNAN, Peter M.; MCLAREN, Scott A.; TENNANT, Michael. The telecommunications act of 1996: §704 of the act and protections afforded the telecommunications provider in the facilities siting context. Michigan Telecommunications and Technology Law Review, v. 3:1, p. 2, 1999. Disponível em: <http://www.mttlr.org/ volthree/mclaren.pdf>. Acesso em: 11 maio 2014.

4 About that subject: MASSIMINO, Leonardo F. La intervención estatal, la regulación económica y el poder de policía: análisis y tendências. Revista de Direito Econômico e Socioambiental, Curitiba, v. 6, n. 1, p. 36-63, jan./jun. 2015. p. 39.
} 
that won the auction) and the principle of dilution of the economic power centers (realized in encouraging competition by dividing the spectrum into sub-bands and lots and by the requirement of waiving the $3 G$ spectrum in the same locality by the winning companies). These circumstances characterize the telecommunications sector, where Law No. 9.472/1997 (the General Telecommunications Law) adopts the principles of competition and universal access as the policy foundation for the sector. Universal access was broadly addressed by the General Plan of Universal Access Goals (Plano Geral de Metas de Universalização - PGMU III) as the binding pillars of the policies for the sector.

However, certain questions should be raised, such as the technical basis used for the adoption of this system, because there may be more viable alternatives. For example, could the determination to expand service to rural areas by the same companies that won the auction, that is, dividing the spectrum into sub-bands and lots and waiving existing licenses (in certain cases, inserted in the public policy for the sector), result in the sector's development, or would this practice discourage investment by forcing investors to make expenditures on activities that are not always profitable? Furthermore, could the desired results be achieved by such instruments, or would a greater liberalization be more practical?

These issues, in a broader view, are profoundly linked to a vision of how the state should act in the economy to foster development. ${ }^{5}$ From a liberal perspective, it can be argued, under a liberal perspective, that determinations of to enable universal access of to the broadband may generate an opposite effect opposite to that intended because it would interfere with the operation of the free market. From another perspective, the requirement would allow facilitate market the expansion of the market, which would result in development by allowing providing access to excluded people individuals to have access and hence thus the right to fully develop their skills abilities as participants in front of modern society. ${ }^{6}$

To obtain at least a few answers to these questions and because the research objectives concern examining the reasons for the government's arguments and the consequences of the demands placed on companies, the most appropriate method is descriptive. This approach includes the establishment of relationships by comparing the current situation of broadband in the telecommunications sector with national and international experience that involved similar incentives. This method does not

\footnotetext{
5 NOHARA, Irene Patrícia. Desafios jurídicos das Parcerias Público-Privadas (PPPs) e desenvolvimento nacional sustentável. Revista de Direito Econômico e Socioambiental, Curitiba, v. 5, n. 2, p. 184-203, jul./dez. 2014. p. 187-190.

6 About that function of Public Administration: DELPIAZZO, Carlos E. Centralidad del administrado en el actual Derecho Administrativo: impactos del Estado Constitucional de Derecho. Revista de Investigações Constitucionais, Curitiba, v. 1, n. 3, p. 7-32, set./dez. 2014. p. 25.
} 
necessarily establish the factors that contribute to a phenomenon's occurrence, something that is difficult to determine in the case of social and economic sciences. ${ }^{7}$

Based on this descriptive perspective, the inductive method also appears relevant. The hypotheses will emerge from the analyses of the current broadband scenario in Brazil, of the incentives (from a developmental perspective) and of other cases that used the same instruments. This approach will facilitate a conclusion that can be "reality tested" because it is grounded in concrete cases. Therefore, the use of an interdisciplinary approach is also necessary, ${ }^{8}$ including mainly concepts from other areas of the exact and economic sciences.

Because the methodological and technical possibilities do not exist, accurate projections are impossible. We intend simply to establish a number of assertions about the public policy to encourage competition and universal access that was employed in granting licenses to operate the new Brazilian broadband sector. Thus, the question of whether this telecommunication service can be developed can be addressed.

\section{Current Broadband Scenario in the Brazilian Telecommunications Sector}

\section{A) Legal Organization of the Sector until the Auction Date}

Until the implementation of the "Telebrás System" (Brazilian Telecommunications [Telecomunicações Brasileiras - Telebras]), the Brazilian telecommunications sector consisted of several local and regional companies, whose operations lacked coordination. This lack of coordination jeopardized the development of a national network, which was essential for communication. The system's effective implementation between the late 1960 s and the early 1970 s followed a centralized format with the state monopoly of the union, which was approved by Article $21, \mathrm{XI}$, of the Federal Constitution of 1988. Such a format was crucial to the development of a national infrastructure, both to coordinate actions throughout the national territory (previously characterized by the disorganization of local actors) and to increase investment. ${ }^{9}$

The centralized model made important contributions. However, a new context emerged for redefining the role of the state in relation to its duties. Here, the late twentieth-century idea of subsidiary operation was revived for application in the early twenty-first century. The idea was based on economic neutrality and the reduction

\footnotetext{
GIL, Antônio Carlos. Como elaborar projetos de pesquisa. São Paulo: Atlas, 2007. p. 42.

DEMO, Pedro. Metodologia do conhecimento científico. São Paulo: Atlas, 2000. p. 65.

9 FARACO, Alexandre Ditzel. Capítulo 2: Regulação das telecomunicações: entre concorrência e universalização. In: SHAPIRO, Mário Gomes (Coord.). Direito e Economia na Regulação Setorial. São Paulo: Saraiva, 2010. p. 36-39.
} 
of state activities. ${ }^{10}$ This new context substantially influenced the rules governing economic sectors related to infrastructure and therefore the telecommunications sector.

This context does not imply that subsidiarity and development are closely linked, particularly in Brazil, where these concepts are not principles. ${ }^{11}$ However, the use of the state subsidiarity criterion as the economic, moral and political ground of a new state model $^{12}$ has resulted in the creation of various legal regulations, in particular, infra-constitutional ones. These regulations transfer the execution of certain public services to the private sector. ${ }^{13}$ Subsidiarity is accepted by much of the doctrine as preventing the state from performing activities that private persons can perform. ${ }^{14}$ Notably, it cannot serve as a basis for limiting state intervention not only because of the weakness of this argument (state action must depend on a democratic process or the republican state's purposes) but also because Article 173 of the Federal Constitution legitimizes direct intervention regardless of the sufficiency of the private sector in the cases listed in the article. ${ }^{15}$

The transition from the state monopoly to a system of private competition began with Constitutional Amendment No. 08/1995, which amended Article 21, XI, of the Federal Constitution and allowed private companies to participate in the implementation of telecommunications services. Additionally, this amendment created a regulatory agency and enacted a law regarding the organization of the service. ${ }^{16}$ The transfer of public telecommunications services through licensing has generated protest against the doctrine. According to Di Pietro, the traditional license is provided in the sole interest of the private person, and, for example, where collective needs are not met, there may be no licenses for providing services under the public regime. ${ }^{17}$ Bacellar Filho also emphasizes the fragility of the institution, which would give the government the right to revoke the grant according to criteria of convenience and opportunity. ${ }^{18}$ However, the Constitutional Amendment No. 08/1995 clearly foresaw the possibility of transferring this service through licensing.

10 GABARDO, Emerson. Interesse público e subsidiaridade. Belo Horizonte: Fórum, 2009. p. 220-221.

GABARDO, Emerson. Interesse público e subsidiaridade. Belo Horizonte: Fórum, 2009. p. 220-246.

2 GABARDO, Emerson. Interesse público e subsidiaridade. Belo Horizonte: Fórum, 2009. p. 221.

13 PLACHA, Gabriel. Os impactos e as perspectivas da regulação estatal sobre as atividades econômicas. Revista de Direito Econômico e Socioambiental, Curitiba, v. 1, n. 2, p. 251-270, jul./dez. 2010. p. 253.

14 DI PIETRO, Maria Sylvia Zanella. Parcerias na Administração Pública - Concessão, Permissão, Franquia, Terceirização e outras formas. 4. ed. São Paulo: Atlas, 2002. p. 26-27.

15 GABARDO, Emerson. Interesse público e subsidiaridade. Belo Horizonte: Fórum, 2009. p. 211-228.

16 About that subject, see: MOURA, Emerson Affonso da Costa. Estado Gerencial, Regulação Econômica e Serviços Públicos: o Papel das Agências na Promoção do Desenvolvimento. A\&C - Revista de Direito Administrativo \& Constitucional, Belo Horizonte, v. 14, n. 57, p. 193-218, 2014.

17 DI PIETRO, Maria Sylvia Zanella. Parcerias na Administração Pública - Concessão, Permissão, Franquia, Terceirização e outras formas. 4. ed. São Paulo: Atlas, 2002. p. 124.

18 BACELLAR FILHO, Romeu Felipe. Concessão, permissão e autorização de serviço publico. In: CARDOZO, José Eduardo Martins; QUEIROZ, João Eduardo Lopes; DOS SANTOS, Márcia Walquriria Batista (Coord.). Direito Administrativo Econômico. São Paulo: Atlas, 2011. p. 405. 
The main objectives of this constitutional reform were in tune with the new context. It was sought to strengthen the intervention under the state's guidance in the economy rather than the state's direct operation. Additionally, incentives were introduced to create a competitive environment among private agents and universal access to services. The General Telecommunications Law (Lei Geral de Telecomunicações LGT), Law No. 9.472/97, was enacted and promulgated with this scope, privatizing the "Telebrás System" and creating a regulatory agency (ANATEL).

The traditional notion of public service itself has been affected by the new law. ${ }^{19}$ Because they are linked to the relations between state and society existing in the historical moment in which they develop, legal institutions reflect such a relationship. ${ }^{20}$ Thus, the need to introduce competition in a particular previously monopolistic sector, such as telecommunications, meant that public services could be provided on a private basis. This approach opposes the classical idea of public service reflected in most Brazilian law, in which such a provision would only occur in a public regime. ${ }^{21}$ In fact, the idea of public service became flexible. ${ }^{22}$

Similarly, articles 61-68 of the General Communications Law (LGT) defined a new classification of services based on their scope, which could be of collective or restricted interest. Collective interest refers to the general public interest. Restricted interest refers to the use of the provider and depends on the legal regime of its provision, which could characterize public or private systems. Therefore, exploratory activity is allowed in both the public and private regimes.

The distinction between public and private regimes is relevant for defining the duties and responsibilities of the federal entity or private agent, although both regimes treat public service. Thus, obligations relating to the public system were established in the LGT. The most important of these obligations are the transmission of the service execution by grant (artigos 83 a 91 da LGT), the collection fees for using the service (artigos 103 a 109 da LGT), the reversibility of goods and, particularly, universal access (General Plan of Universal Access Goals - Plano Geral de Metas de Universalização PGMU) and continuity. These obligations are guaranteed by the Union (artigos 79 a 82 da LGT), for which the normative power of this federative entity in choosing and qualifying an activity to be provided under the public regime was also maintained by

\footnotetext{
19 MARTínEZ, Augusto Durán. Estado Constitucional de Derecho y Servicios Públicos. A\&C - Revista de Direito Administrativo \& Constitucional, Belo Horizonte, v. 15, n. 60, p. 39-59, 2015; HACHEM, Daniel Wunder. Direito fundamental ao serviço público adequado e capacidade econômica do cidadão: repensando a universalidade do acesso à luz da igualdade material. A\&C - Revista de Direito Administrativo \& Constitucional, Belo Horizonte, ano 14, n. 55, p. 123-158, jan./mar. 2014.

20 GROTTI, Dinorá Adelaide Musetti. Teoria dos serviços públicos e sua transformação. In: SUNDFELD, Carlos Ari (Coord.). Direito Administrativo Econômico. São Paulo: Malheiros, 2006. p. 36.

21 GROTTI, Dinorá Adelaide Musetti. Teoria dos serviços públicos e sua transformação. In: SUNDFELD, Carlos Ari (Coord.). Direito Administrativo Econômico. São Paulo: Malheiros, 2006. p. 42-43.

22 MARQUES NETO, Floriano Azevedo. Direito das telecomunicações e ANATEL. In: SUNDFELD, Carlos Ari (Coord.). Direito Administrativo Econômico. São Paulo: Malheiros, 2006. p. 308.
} 
decree (artigo 18, I, da LGT). The only exception to such discretion was the FSTS, which is vitally important to the system because it supports the provision of telecom services, not only the fixed service. Regarding the private sector, the main rules for the service are the transmission through license, the possibility of collecting public price freely, the non-reversibility of goods and the non-compulsoriness of universal access and continuity by the union.

Actually, this division of regimes is at the center of the two principles that guide the regulation of the telecommunications sector: competition and universal access. This sector has two peculiarities that require the public law applied to it to modify itself to maintain its effectiveness: a greater influence of technological advancement and a legal subsystem within the system itself. These peculiarities transform the useless and antiquated legal tools applied in this economic area. ${ }^{23}$ The traditional principles applied to public service, such as the principle of continuity, which gravitated around the idea of "adequate service" (Lei 8.987/95) were insufficient to foster a competitive environment. ${ }^{24}$ Thus, Grotti advises that changes to the state model resulted in a new principle that would be friendlier to the regulation model of competitive public services: the principle of vertical disintegration of the distinct phases or segments of a business (unbundling). In this model, the segments provided by competing operators in competition would be distinguished in it. Common to all, the infrastructure, and another singled out, the service itself. Based on this division, it would be possible to distinguish competitive and non-competitive activities for the application of different legal systems for each activity type, as well as greater transparency of information through the elimination of cross-subsidiesy. ${ }^{25}$

The new system was based on two premises. As previously mentioned, the first one would be the cessation of direct guidance by the state, which counter-intuitively substantially increased its regulatory role. The second would be the legal balance between the two main principles: universal access and competition. Universal access would seek to reach potential users, whereas competition would seek the effective user. Such a balance would be achieved using regulatory asymmetry between providers in the public system, who would be obliged to furnish universal access, and providers in the private system, who would not be obliged to do so (other than by the possibility of interconnecting networks). ${ }^{26}$

\footnotetext{
23 MARQUES NETO, Floriano Azevedo. Direito das telecomunicações e ANATEL. In: SUNDFELD, Carlos Ari (Coord.). Direito Administrativo Econômico. São Paulo: Malheiros, 2006. p. 301-302.

24 GROTTI, Dinorá Adelaide Musetti. Teoria dos serviços públicos e sua transformação. In: SUNDFELD, Carlos Ari (Coord.). Direito Administrativo Econômico. São Paulo: Malheiros, 2006. p. 49.

25 GROTTI, Dinorá Adelaide Musetti. Teoria dos serviços públicos e sua transformação. In: SUNDFELD, Carlos Ari (Coord.). Direito Administrativo Econômico. São Paulo: Malheiros, 2006. p. 62-63.

26 MARQUES NETO, Floriano Azevedo. Direito das telecomunicações e ANATEL. In: SUNDFELD, Carlos Ari (Coord.). Direito Administrativo Econômico. São Paulo: Malheiros, 2006. p. 306-308.
} 
Therefore, basically, universal access would be provided for the segment in which there would be no infrastructure or access, thus would connecting it it to the public service provided in the public regime, and competition would be applied to the segment in which it was possible, with public service provided in a private regime.

After the establishment of this general framework by LGT (before concessions were made), the Union initially enacted a General Concession Plan (Plano Geral de Outorgas - PGO) through Decree 2.534/98 to establish competition in the various regions of the country. The goal was the provision of infrastructure by a concessionaire and the operation of service by a competitor (a mirror company) that operated according to the private regime under the legal form of a license. Thus, a duopoly system would be created in each region.

Universal access included two situations: individual telecommunications services that should be provided at reasonable fees to any person or organization and other forms of individual access to telecommunications services without the economic condition of paying commercially reasonable rates for individual services. Thus, Decree $4.733 / 03$ established that public policies related to telecommunications services should ensure individual access for all citizens to at least one telecommunication service and the Internet at reasonable rates.

In recent years, seeking to achieve the established principles and because of technological convergence and the rapid evolution of the telecommunications sector, ANATEL has elaborated the General Plan of Update of Regulation of Telecommunications in Brazil (Plano Geral de Atualização da Regulamentação das Telecomunicações no Brasil - PGR), which was approved by Resolution No. 516/2008. This resolution represents ANATEL's strategic planning for the next ten years and aims to update the regulation of telecommunications in Brazil while generating transparency and predictability. ${ }^{27}$

From the framework described here, both inaugural laws (Constitutional Amendment No. 08/1995 and the LGT) have created three regulatory spaces: telecommunications in the strict sense; the control of the radio frequency spectrum, which does not distinguish the service provided and whose regulation is performed by ANATEL following the public policy for the sector; and radio diffusion with the regulation of the Ministry of Communications. Such boundaries may be subject to tension or overlapping activities, which may cause confusion in the regulation of areas. These areas include the implementation of mobile operator infrastructure, whose regulation toward universal access was determined by decree, and the costly licensing of multichannel multipoint distribution services (MMDS) frequencies, which

\footnotetext{
27 PENA, André Garcia; ABDALLA JÚNIOR, Humberto; PEREIRA FILHO, José Leite. A banda larga e o cenário brasileiro das telecomunicações. Revista de Direito, Estado e Telecomunicações, v. 4, n. 1, p. 237-302, 2012. p. 241.
} 
are regulated by ANATEL. ${ }^{28}$ In this case, we can clearly observe a loss of space in the debate on the latter problem, which concerns the reallocation of frequency bands for the expansion of cellular telephony (PMS).

\section{B) Overview of the Telecommunications Infrastructure}

For public policies and regulation to achieve their goals of competition and universal access, the current state of the telecommunications sector infrastructure must be understood. Such understanding facilitates identifying deficiencies related to access and network capacity as well as the sector's dominant companies. According to Pena, Abdalla Junior and Pereira Filho, the precise identification of the installed infrastructure facilitates the adoption of pro-competition measures, such as resource sharing, given that one problem in telecommunications is the high cost of the network implementation, which acts as a barrier to the entry of new competitors. ${ }^{29}$

The primary telecommunications infrastructures are the broadband access networks, the transport networks and the international connections. The first provides the user access to the service (the so-called last mile or local loop) and is divided according to terminal mobility into fixed and mobile networks. The second connects the various metropolitan networks throughout the country, which are divided into transmission networks of high capacity (backbone) and primary distribution networks of high capacity (backhaul). The third connects national networks to international networks through submarine optical cables or satellites..$^{30}$ In the analysis presented here, only the verification of the broadband access networks is required, more specifically, the mobile access networks.

\section{Broadband Through Mobile Access}

"Broadband" refers to high-speed connections as opposed to "narrowband" (a 64 kbps connection that uses the telephone channel). The evolution of telecommunications networks has resulted in the creation of new high-capacity connections, which replaced dial-up connections and increasingly consumed more network resources. Originally, legacy networks that provided specific services, such as switched networks that offered only fixed telephony or cable TV networks that distributed only

\footnotetext{
28 Direito, Estado e Telecomunicações: fronteiras institucionais regulatórias. [Editorial]. Revista de Direito, Estado e Telecomunicações, v. 5, n. 1, p. 1-28, 2013. p. 5-6.

29 PENA, André Garcia; ABDALLA JÚNIOR, Humberto; PEREIRA FILHO, José Leite. A banda larga e o cenário brasileiro das telecomunicações. Revista de Direito, Estado e Telecomunicações, v. 4, n. 1, p. 237-302, 2012. p. 241-242.

30 PENA, André Garcia; ABDALLA JÚNIOR, Humberto; PEREIRA FILHO, José Leite. A banda larga e o cenário brasileiro das telecomunicações. Revista de Direito, Estado e Telecomunicações, v. 4, n. 1, p. 237-302, 2012. p. 241-242.
} 
unidirectional audiovisual content, were digitized. In addition to increasing system capacity, digitization enabled the transfer of any type of content, the so-called "Technological Convergence". The new technologies included three types of broadband access: wireline, wireless and satellite. ${ }^{31}$

The wireless broadband access networks (fixed and mobile) replaced wired networks. They enabled terminals to be mobile, including cellular telephones (hand-off). ${ }^{32}$ The primary technologies used to provide access through wireless networks are Wi-Fi, WiMAX and mobile technologies ( $3 G$ and $4 G$ ). Therefore, expanding the use of personal communication service (PCS) in mobile technology is only possible with the expansion of the global system for mobile communications (GSM), which is the mobile network infrastructure that provides users access to the service (the local loop). Universal access should be focused at this point.

Because these technologies are evolving rapidly, the National Broadband Plan (Programa Nacional de Banda Larga - PNBL) was created by Decree 7.175/10 with the goal of expanding the infrastructure and telecommunications services to provide broadband access to 40 million Brazilian households by 2014 at a speed of at least $1 \mathrm{Mbps}$. The program has several aims, including the licensing of the broadband frequency spectrum at the $2.5 \mathrm{GHz}$ band, which will enable the provision of high-speed mobile broadband (4G), and at $450 \mathrm{MHz}$, which will expand rural telephony and broadband Internet services. The PNBL was the first legal instrument to define the term "broadband" as the provision of telecommunications infrastructure that facilitates continuous and uninterrupted information traffic with sufficient capacity for the most common or socially relevant data, voice and video applications. The concept is indifferent to the employed technology and does not restrict mobility and portability.

\section{C) Normative Framework of Mobile Broadband Access}

After these preliminary considerations, we can establish the basic normative framework that regulates the exploitation of this public good and according to which the ANATEL auction of radio frequency licenses was conducted. This step is relevant because it will demonstrate whether the legal stimuli in the sector can actually develop the infrastructure and service provision.

With only several differences regarding nomenclature remaining, the main normative reference is the LGT. Without making considerations of constitutional

\footnotetext{
31 PENA, André Garcia; ABDALLA JÚNIOR, Humberto; PEREIRA FILHO, José Leite. A banda larga e o cenário brasileiro das telecomunicações. Revista de Direito, Estado e Telecomunicações, v. 4, n. 1, p. 237-302, 2012. p. 275-276.

32 PENA, André Garcia; ABDALLA JÚNIOR, Humberto; PEREIRA FILHO, José Leite. A banda larga e o cenário brasileiro das telecomunicações. Revista de Direito, Estado e Telecomunicações, v. 4, n. 1, p. 237-302, 2012. p. 279.
} 
order will not be considered because there are no doubts regarding the possibility of transferring the service implementation to private agents or the possibility of direct implementation by the Union. The LGT determined that the exploitation of the radio frequency service (operations performed by accessing wireless networks through mobile technologies) would occur according to a private regime based on a previous approval from ANATEL (artigo 131, §1으, LGT). The law also devoted Chapters I and II of Title $V$ to the radio frequency spectra. It was determined that these spectra represent a limited resource, thus becoming a public good to be managed by ANATEL (artigo 157, LGT) whose use will or will not have an exclusivity character and will depend on a prior grant from the same agency of a license (artigo 163, LGT). This license for use is an administrative act with its reason expressed in law and is associated with the concession, permission or authorization to provide telecommunications service. ${ }^{33} \mathrm{It}$ assigns to the concerned party for a specified period the right to use a radio frequency under the relevant legal and regulatory conditions (artigo 163, §1ํㅡ, LGT). As previously noted, in addition to these specific items, all rules governing the services provided according to a private regime apply (Título III da LGT).

Within the relevant adopted public policies, the public good must still be contained in the National Broadband Plan (Decreto no 7.175/10) and the General Plan of Universal Access Goals for the Fixed Switched Telephone Service (Plano Geral de Metas de Universalização para o Serviço Telefônico Fixo Comutado - PGMU III Decreto $n=7.512 / 2011$ ). This plan has been decisive for the inclusion of the granting of licenses to use of radio frequencies in the $450 \mathrm{MHz}$ band, which are essential bands for meeting the established goals there.

More specifically, Resolution No. 544/10 re-enacts and amends the Regulation on the Conditions of Use (Regulamento sobre Condições de Uso) of radio frequencies from 2,170 MHz to 2,182 MHz and from 2,500 MHz to 2,690 MHz. The worldwide use of these frequencies was standardized by the International Telecommunications Union (ITU) for use in mobile communications. The tender proposal is aligned with the recommendations of the ITU and the Inter-American Telecommunication Commission (CITEL).

Accordingly, the invitation to tender was prepared with the purpose of implementing the provisions contained in the General Plan of Update and Regulation of Telecommunications in Brazil (Plano Geral de Atualização da Regulamentação das Telecomunicações no Brasil - RMP) and approved by Resolution No. 516/2008 in compliance with Resolution No. 544/10 and the previously noted dispositives.

\footnotetext{
${ }_{33}$ NUNES, Luciana Gonçalves. Finalidades e limitações da intervenção do Estado na economia sob a ótica da Constituição da República de 1988. Revista de Direito Econômico e Socioambiental, Curitiba, v. 2, n. 1, p. 83-99, jan./jun. 2011. p. 86.
} 


\section{Public Policy Requirements for the Sector at the Invitation to Tender}

As stated, on June 12, 2012, the ANATEL auction was conducted to tender the radio frequency bands (known as $4 \mathrm{G}$ technology) of $2.5 \mathrm{GHz}$ (national coverage) and $450 \mathrm{MHz}$ (the rural area). The auction winners were Claro, Vivo, Tim and Oi, of which the first two companies won the frequencies with the larger coverage capacity. In the analysis of the auction, can be noted several cases in which the regulation of the sector sought universal access and competition.

Already prior to the issue of the invitation to tender, the PGMU III (Decreto no 7.512/2011) assigned to ANATEL the adoption of regulatory measures to establish quality standards for $4 \mathrm{G}$ telecommunications services and rules on advertising and transparency to assess the quality perceived by users (Art. $2^{\circ}$ ). ANATEL was also assigned the expansion of access to telecommunications by granting licenses to use the radio frequency sub-bands from $451 \mathrm{MHz}$ to $458 \mathrm{MHz}$ and from $461 \mathrm{MHz}$ to $468 \mathrm{MHz}$ and to require from the grantees counterparts in the form of services to rural and remote regions. Two principals were to be observed: (i) the gradual expansion of the service penetration in rural areas and remote regions through selection criteria based on the lowest price of service plans for the final consumer and (ii) the principle of providing free broadband Internet access in all public schools in rural areas.

Based on the Decree, ANATEL issued the Resolution No. 544/2010 to modify the allotment and regulate the use of radio frequencies in the currently used bands, as well as those that would be tendered, where the joint tendering for use of the $450 \mathrm{MHz}$ band along with the $2.5 \mathrm{GHz}$ band arouse. This joint tender actually reverberates an old expedient in the telecommunications sector known as, cross-subsidy, which is the transfer of funds from a one particular segment to another so that the beneficiary segment can pay lower values rates. ${ }^{34}$ The practice is, widely used in the implementation Brazilian telecommunications. Despite its prohibition by LGT (Art. 103, parágrafo $2^{\circ}$ ) because the practice entails distortions to competition. However, the article 81, sole paragraph 1 of the same law allows its use until a special fund for universal access is created. This fund already exists (Fust). However, its use was restricted to companies that are active within the public regime as determined by the Federal Court of Accounts (Tribunal de Contas da União - TCU). ${ }^{35}$

\footnotetext{
34 Subsídio cruzado consiste na transferência de recursos obtidos num determinado segmento para outro, a fim de que o segmento beneficiado possa pagar valores mais baixos. CÂMARA, Jacinto Arruda. Tarifa nas concessões. São Paulo: Malheiros, 2009. p. 79.

35 FARACO, Alexandre Ditzel. Capítulo 2: Regulação das telecomunicações: entre concorrência e universalização. In: SHAPIRO, Mário Gomes (Coord.). Direito e Economia na Regulação Setorial. São Paulo: Saraiva, 2010. p. 78-79.
} 
Because the radio frequency spectrum is a public good of limited resources managed by ANATEL, it fell to ANATEL, within its reasonable discretionary judgment, to decide in a motivated way to jointly tender licenses for the use of the $450 \mathrm{MHz}$ and $2.5 \mathrm{GHz}$ bands. ANATEL's technical department demonstrated that the proposed tendering model would ensure the viability of operations in both bands. Regarding the tender, it was established that the bands would first be auctioned separately. At the beginning, only the use of the $450 \mathrm{MHz}$ band would be tendered. If there was no winner in this first stage of the tender, there would be a joint tendering of the bands.

Thus, within the presented normative framework, there is no legal impediment to the proposal of a joint tender of the $2.5 \mathrm{GHz}$ and $450 \mathrm{MHz}$ bands. Furthermore, in the case of a joint tendering, the imposition of obligations on the part of the winning bidder is possible. Such a system has been adopted by ANATEL for some time and can be seamlessly implemented with the assumption by the winner of commitments in favor of the community, for example, the implementation of support to provide services in rural areas. Commitments are made based on LGT articles 135 and 136, paragraph 3, among other articles. In this regard, Decree 7.512/2011 determines, regarding the $450 \mathrm{MHz}$ band, that the tender requires counterparts from the winners in the attendance form of rural areas and remote regions. It is worth noting that the tender was for the use of radio frequencies, a public good that in this case could be used for the operation of PMS and MCS.

Another requirement is found in article 11 of Resolution No. 544/2010, which establishes guidelines for the licenses to use radio frequencies acquired in new tendering processes: certain "spectrum" limits should be respected. That is, it was clearly established that to use $4 G$ technology, providers should renounce the use of existing licenses in the same locations, in this case, to use $3 G$ technology. Thus, by limiting the auction participants, ANATEL promoted competition by encouraging the diverse entry of new providers in the $2.5 \mathrm{GHz}$ band in specific market niches. ANATEL's goal was to have five companies operating in the same geographic area. This restriction is intended to prevent the domination of this scarce public good (the radio frequency spectrum) by one or a few companies and to stimulate competitiveness in the sector, aiming at increasing competition and preventing a particular provider to have monopoly or exaggerated concentration of the use of the good.

Finally, Invitation to Tender No. 004/2012/PVCP/SPV was published. This tender would initiate the dispute following the framework of Resolution No. 65/98 (tender rules under the scope of ANATEL). In addition to establishing the obligation to waive the use of existing licenses (according to the limits established in article 11 of Resolution No. 544/2010), limits were re-defined in the Invitation to Tender in items A.1, A.2, A.3, B, C and C.1 of annex II-D (Conditions for the Participation in the Tender and Use of Radio Frequency Sub-Bands). Accordingly, the division of the 
tendered object into radio frequency sub-bands, which were grouped into lots for auction according to item I, and of the invitation to tender could be verified. Both measures are aimed at enhancing competition.

\section{Previous National Experience in the Search for Universal Access to 3G Technology and Several Points Regarding Competition}

Mobile networks for broadband access using $3 G$ technology were implemented beginning in 2007 with two operators on the $850 \mathrm{MHz}$ band. Similar to the tender of $4 \mathrm{G}$ technology, which aimed to expand the provision of services based on this technology, Invitation to Tender No. 002/2007/SPV sought to guarantee PMS coverage in all Brazilian municipalities by 2010 and the diffusion of $3 G$ technologies throughout the country by requiring various obligations to be assumed by the concessionaires who purchased the sub-bands. The goal was to benefit isolated regions primarily inhabited by low-income individuals whose financial interest was negligible to the operators. This goal was achieved by including a requirement in the invitation to tender related to the injunction to provide service to areas of high interest and to less attractive areas, as described for the $4 G$ technology auction. Operators who purchased sub-bands lots in developed regions were forced to acquire lots in the Northern and Northeastern Regions. Thus, ANATEL harmonized the provision of a service in the private regime (of collective interest) with counterparts that aimed to democratize the access to mobile telephony.

According to Pena, Abdalla Junior and Pereira Filho, in mid-2010, Brazil reached 185 million mobile terminals and service penetration (the number of lines per 100 inhabitants) reached 95.92. In the Midwestern, Southern, and Southeastern Regions, this indicator exceeded 100. That is, there were more operating terminals than inhabitants. However, these researchers assert that because density surpassed this limit does not necessarily imply that the entire population of a given locality has a mobile access terminal. Rather, it implies that there are individuals who possess more than one mobile device or devices with more than one chip. In addition, terminals used exclusively for data communication ( $3 G$ modems) and active chips that have not been enabled influence the calculation of this indicator. Regarding $3 G$ terminals (cellular telephones and modems), at this time, Brazil has 15 million units, with low penetration in the Northern and Midwestern Regions. Using ANATEL data, the same researchers also found that at the end of 2009, GSM technology was the most used in the country for the provision of PMS, accounting for over $90 \%$ of access. Because of the investment of providers in the GSM network and 3G technology, the percentage of wideband code division multiple access (WCDMA) doubled between 2008 and 2009 
from $1.1 \%$ to $2.3 \%$. As a result of the growth of mobile broadband, access for data transmission increased from $0.4 \%$ to $2.6 \%{ }^{36}$

From these data, it can be concluded that between the 3G technology tender invitation (2007) and the year of the Brazilian National Household Survey (PNAD) (2009) (or, as an alternative to the latter, 2010 ANATEL data), there has been progress in the expansion of $3 G$ technology for PMS use throughout the country, although the service has not yet reached several less populated regions.

At the time the initial fixed network system for FSTS and CMS (the mobile service that preceded PMS) was implemented, the adopted mechanisms had perhaps failed to apportion competition. Both systems began under a duopoly: CMS with bands A and $B$ and FSTS with concessionaires and mirror companies. However, regarding the latter, evolution was found only regarding long-distance calls, and although there were many licenses, they related only to a few market niches. In fact, the concessionaires (former state companies) expanded their operation area and the type of service provided to include fixed telephony, data transmission and mobile telephones. Today, these large companies seek the so-called "triple play": the joint sale of voice (FSTS, of which PMS and the voice-over-Internet protocol (VolP are also part), data (MCS, broadband) and audiovisual (MMDS, cable, satellite) transmission services. Therefore, it seems that there was no consolidation of other companies to compete with the companies purchasing the entire previously installed public network. However, there was a substantial increase in competition regarding the mobile telephony market in which these concessionaires disputed the market with groups formed from the duopoly established for CMS, which resulted in a rapid service expansion. ${ }^{37}$

\section{Some International Experiences}

The description of some international experiences in the sector, which used the same public policy mechanisms adopted in Brazil, has a substantial value to be used, if not as a parameter, as data intended for developing assertions about its effectiveness.

In an article on the diffusion of mobile telecommunications in Central and Eastern Europe, Gruber states that for many decades, the telecommunications market was based on a natural monopoly (as in Brazil). This natural monopoly became untenable with the development of mobile technology, particularly with the change from an

\footnotetext{
36 PENA, André Garcia; ABDALLA JÚNIOR, Humberto; PEREIRA FILHO, José Leite. A banda larga e o cenário brasileiro das telecomunicações. Revista de Direito, Estado e Telecomunicações, v. 4, n. 1, p. 237-302, 2012. p. 243-258.

37 FARACO, Alexandre Ditzel. Capítulo 2: Regulação das telecomunicações: entre concorrência e universalização. In: SHAPIRO, Mário Gomes (Coord.). Direito e Economia na Regulação Setorial. São Paulo: Saraiva, 2010. p. 48-52.
} 
analog to a digital system. This change substantially increased the efficient use of the frequency spectrum, which expanded the market and enabled the participation of a larger number of competing companies. As a result, the spread of the service accelerated. Gruber emphasizes the importance of mobile technology in the expansion of telecommunications as opposed to fixed technology, which has much higher costs and poses greater difficulties for companies to raise capital. ${ }^{38}$ Gruber also reports that after the fall of communism in the countries of this region, the sector's development was driven by social and political obligations imposed on the companies. The aim was to provide the services to every household at low prices. However, these obligations were not specified exactly, which resulted in the understanding, according to Gruber, that they were intended to increase competition. ${ }^{39}$ In his conclusion, Gruber argues that mobile service was not substituted for fixed service to provide universal access to telecommunications because the former depends in part on the infrastructure of the latter. Additionally, many calls are made between mobile and fixed devices. Nevertheless, the diffusion of the mobile service through increased competition may serve as a complement to the fixed service, which is extremely important for the sector's development. ${ }^{40}$ This history may be useful to the joint tender of the $2.5 \mathrm{GHz}$ and $450 \mathrm{MHz}$ bands, of which the latter will be employed in rural areas.

Regarding cross-subsidies in telecommunications, Kaserman, Mayo and Flynn state emphatically that such subsidies are useless for development. Based on an analysis of empirical results, they demonstrate that such policy has no causal relationship with the goal of universal access and observe that subsidies and subscription fees are determined by economic variables such as those described in the theories of competitive market regulation. ${ }^{41}$ Conversely, Majumdar and Chang conclude that in the U.S. the funds generated by cross-subsidies were invested by companies in technology diffusion and digital technology development. The subsidies played a positive role in providing the capital that these companies required to expand consumer access. ${ }^{42}$ Interestingly, if cross-subsidies are used in a free

38 GRUBER, Harald. Competition and innovation: the diffusion of mobile telecommunications in Central and Eastern Europe. Information Economics and Policy, n. 13, Elsevier, mar. 2000. Disponível em: <http://ssrn. com/abstract=191989 or http://dx.doi.org/10.2139/ssrn.191989>. Acesso em: 26 jul. 2013. p. 2.

39 GRUBER, Harald. Competition and innovation: the diffusion of mobile telecommunications in Central and Eastern Europe. Information Economics and Policy, n. 13, Elsevier, mar. 2000. Disponível em: <http://ssrn. com/abstract=191989 or http://dx.doi.org/10.2139/ssrn.191989>. Acesso em: 26 jul. 2013. p. 4.

40 GRUBER, Harald. Competition and innovation: the diffusion of mobile telecommunications in Central and Eastern Europe. Information Economics and Policy, n. 13, Elsevier, mar. 2000. Disponível em: <http://ssrn. com/abstract=191989 or http://dx.doi.org/10.2139/ssrn.191989>. Acesso em: 26 jul. 2013. p. 14.

41 KASERMAN, David L.; MAYO, John W.; FLYNN, Joseph E. Cross-subsidization in telecommunications: Beyond the universal service fairy tale. Journal of Regulatory Economics, v. 2, p 231-249, set. 1990. p. 246.

42 MAJUMDAR, Sumit K.; CHANG, Hsihui. Regulations and Technology Diffusion: Cross Subsidies and Digital Infrastructure Creation. Annals of Public and Cooperative Economics, 84, p. 159-178, 2013. p. 174. 
market only for certain companies while others are prohibited from using them, coercive regulatory intervention is required to prevent the market from destabilizing and damaging competition. ${ }^{43}$

\section{The requirements of the Invitation to Tender and the Development issue}

The development issue is highly interesting to legal scholars but causes uncertainty because it is important and requires definition. This definition is difficult with a term whose range of meanings within a single discipline and for each school within a discipline generates heated discussion. Here, efforts will be made to use the views of a limited number of development researchers, which may contribute to disentangling the central issues: (i) Can universal access and competition with respect to $4 \mathrm{G}$ mobile technology and wireless networks generate development? (ii) Could the public policy requirements for the sector regarding the invitation to tender generate universal access and competition, or would other methods be more efficient?

However, it is first relevant to note that communication services are highly important in economic development. Using economies of scale and exhibiting network effects, such services generate benefits that encourage innovation in other sectors in a spillover effect. In this context, broadband has become the most robust platform for facilitating economic development and new business models and for stimulating innovation in numerous sectors. ${ }^{44}$

Regarding the first question, it is important to examine the relationship between the constitution and development. ${ }^{45}$ This relationship is difficult to grasp because it implies certain difficulties, such as the reciprocity of possible causal relations between both concepts, the Federal Constitution's lack of universality (given its historical mutability) or its variable efficacy. However, aspects of the Federal Constitution

43 FAULHABER, Gerald R. Cross-Subsidization: Pricing in Public Enterprises. The American Economic Review, v. 65, n. 5, p. 966-977, 1975. Nashville: American Economic Association. Disponível em: <http://www.jstor. org/stable/1806633>. Acesso em: 26 jul. 2013. p. 170.

44 DAVIDSON, Charles M.; SANTORELLI, Michael J. Seizing the Mobile Moment: Spectrum Allocation Policy for the Wireless Broadband Century. CommLaw Conspectus Journal of Communications Law and Policy. Washington: Columbus School of Law (Catholic University of America), v. 19, Issue 1, 2010. Disponível em: <http:// commlaw.cua.edu/res/docs/articles/v19/19-1/05-v19-1-REVISED-DavidsonSantorelli-Final.pdf>. Acesso em: 10 maio 2014.

45 About that relation, it is important to check: HACHEM, Daniel Wunder. A noção constitucional de desenvolvimento para além do viés econômico: reflexos sobre algumas tendências do Direito Público brasileiro. A\&C-Revista de Direito Administrativo \& Constitucional, Belo Horizonte, ano 13, n. 53, p. 133-168, jul./set. 2013; ESTEVES, Henrique Perez. Ativismo normativo na aplicação constitucional do desenvolvimento sustentável. Revista de Direito Econômico e Socioambiental, Curitiba, v. 5, n. 1, p. 91-109, jan./jun. 2014, and NOBRE JÚNIOR, Edilson Pereira. Uma ideia de Constituição. Revista de Investigações Constitucionais, Curitiba, v. 1, n. 1, p. 111-145, jan./abr. 2014. p. 138-139. 
influence development by regulating rights and property, the forms of government and fundamental rights. ${ }^{46}$

Despite these difficulties, the idea that underlies these concepts is positive. The Federal Constitution and development connote the emancipation of humanity, whereby the Federal Constitution is related to the restriction of arbitrary political power and development addresses the satisfaction of material and spiritual needs. ${ }^{47}$ This statement does not address the criticism of certain scholars who have discussed the need to reduce expectations regarding the influence of the law as a component of development, given the complexity of the legal system and the difficulty of modifying it using simplistic ideas. ${ }^{48}$

Development has acquired legal force in Brazil by being elevated to the status of a fundamental goal of the republic, according to Article 3, Section II of the Federal Constitution. ${ }^{49}$ This section should be read in conjunction with the other sections of Article 3 because the idea of development should involve not only a guarantee but also development's promotion by the Brazilian state. Accordingly and based on an analysis of the beginning of Article 170, we could state that national development is to be achieved through Brazil's economic order, which is founded on the appreciation of human labor and free enterprise. These factors should support the Brazilian state (artigo $1^{\circ}$, IV) with the ultimate goal of ensuring a dignified existence for all. This goal is primarily associated with the social rights described in Article 6 of the Federal Constitution. ${ }^{50}$

Yet there is the a right to development resulting from the article $5^{\text {th }}$; paragraph $2^{\text {nd }}$, of the Federal Constitution, ${ }^{51}$ and Brazil incorporates the legislation of public international law, which addresses sustainable development, for example, Agenda $21 .{ }^{52}$ Other authors

46 VIEIRA, Oscar Vilhena; DIMOULIS, Dimitri. Constituição e desenvolvimento. In: LIMA, Maria Lúcia L. M. Padua (Coord.). Agenda Contemporânea - Direito e Economia - 30 anos de Brasil. t. 1, Série GVLaw. São Paulo: Saraiva, 2012. p. 382-383.

47 VIEIRA, Oscar Vilhena; DIMOULIS, Dimitri. Constituição e desenvolvimento. In: LIMA, Maria Lúcia L. M. Padua (Coord.). Agenda Contemporânea - Direito e Economia - 30 anos de Brasil. t. 1, Série GVLaw. São Paulo: Saraiva, 2012. p. 386.

48 BARRAL, Welber. Desenvolvimento e sistema jurídico: a busca de um modelo teórico. In: BARRAL, Welber; PIMENTEL, Luiz Otávio (Org.). Teoria jurídica e desenvolvimento. Florianópolis: Fundação Boiteux, 2006. p. 29.

49 BERCOVICl, Gilberto. Revolution trough Constitution: the Brazilian's directive Constitution debate. Revista de Investigações Constitucionais, Curitiba, v. 1, n. 1, p. 7-18, jan./abr. 2014.

50 HACHEM, Daniel Wunder. Mínimo existencial y derechos económicos y sociales: distinciones y puntos de contacto a la luz de la doctrina y jurisprudencia brasileñas. Revista Eurolatinoamericana de Derecho Administrativo, Santa Fe, v. 1, n. 1, p. 93-138, ene./jun. 2014. From the perspective of the Argentine Constitution: BALBíN, Carlos F. Un Derecho Administrativo para la inclusión social. A\&C - Revista de Direito Administrativo \& Constitucional, Belo Horizonte, v. 14, n. 58, p. 105-131, 2014.

51 See more about that in: RESENDE, Augusto César Leite de; Gabardo, Emerson. A atividade administrativa de fomento na gestão integrada de resíduos sólidos em perspectiva com o desenvolvimento sustentável. $A \& C-$ Revista de Direito Administrativo \& Constitucional, Belo Horizonte, ano 13, n. 53, p. 105-131, jul./set. 2013.

52 FINGER, Ana Claudia; QUETES, Regeane Bransin. Licitações e contratos administrativos sustentáveis como um instrumento de concretização da supremacia do interesse público. A\&C - Revista de Direito Administrativo \& Constitucional, Belo Horizonte, v. 14, n. 57, p. 33-60, 2014; COELHO, Rafael Isaac de Almeida. Licitação sustentável em concessão de energias renováveis. Revista de Direito Econômico e Socioambiental, Curitiba, v. 5, n. 2, p. 79-96, jul./dez. 2014. 
recognize the right to development implied in the Federal Constitution as closely linked to the democratic values expressed housed there, whose social rights are enshrined in the Article $6^{\text {th }} .53$

The same would occur relative to the purpose of the economic order stipulated in the beginning of Article 170 of the Federal Constitution and with respect to public services, where the state has the duty to act as a regulator (artigo 174 da Constituição Federal) or to provide public services (artigo 175 da Constituição Federal). Without belaboring the definition of public services, we could say that such services are related to activities connected with sustainable national development because the effectiveness of such development is closely linked to the social rights guaranteed in Article 6, particularly the infrastructure required for development's realization. ${ }^{54}$ Therefore, it seems that the obligation of universal access imposed by the public policy for the telecommunications sector is consistent with the developmental question of the Federal Constitution because this policy seeks to ensure the provision of mobile telephony services to a greater number of inhabitants.

After establishing the relationship between the Federal Constitution and development, it is important to examine other concepts outside the normative framework. According to Rister, development in an objective sense must be understood as an ideal to be achieved, an ideal that can be deduced from the constitutional principles related to it, which should guide common law and public policies, as was previously observed. In a subjective sense, the idea of development should consider the agents responsible for development or development's beneficiaries because development is linked to fundamental human rights. ${ }^{55}$ Well, under this regard, what would be the purpose of the obligation to provide universal access to the telecommunications services if not development because it would create greater access? And the prediction that larger actors will work in the sector through competition? Would not it generate a greater predictability for economic agents?

From this subjective perspective, there is also the developmental theory of Sen. Generally, according to this author, development should be observed as a process of expanding the real freedoms of the people, which would allow for their free status

\footnotetext{
53 The judicial activism in the field of social rights has grown strong in Brazilian Courts. On that subject, see: PERLINGEIRO, Ricardo. Recognizing the public right to healthcare: the approach of Brazilian courts. Revista de Investigações Constitucionais, Curitiba, v. 1, n. 1, p. 19-37, jan./abr. 2014, and VALLE, Vanice Regina Lírio do. Judicial adjudication in housing rights in Brazil and Colombia: a comparative perspective. Revista de Investigações Constitucionais, Curitiba, v. 1, n. 2, p. 67-102, maio/ago. 2014.

54 SHIRATO, Vitor Rhein. A regulação dos serviços públicos como instrumento para o desenvolvimento. Interesse Público - IP, Belo Horizonte, ano 7, n. 30, mar./abr. 2005, p. 2. In the perspective of Agentine Law, see: AGUILAR VALDEZ, Oscar Rafael. Reflexiones sobre la titularidad y el título de intervención estatal en las infraestructuras públicas. Revista de Direito Econômico e Socioambiental, Curitiba, v. 6, n. 1, p. 114-139, jan./jun. 2015.

55 RISTER, Carla Abrantkoski. Direito ao desenvolvimento: antecedentes, significados e consequências. Rio de Janeiro: Renovar, 2007. p. 82-83.
} 
as agents, and this requires the removal of the major sources of their deprivation. Five types of freedom help promote an individual's overall ability: political freedom, economic facilities, social opportunities, transparency guarantees and protective security. The ideal instrument for achieving each freedom is public policy. ${ }^{56}$ Not much effort is required to verify that the joint tendering of the $450 \mathrm{MHz}$ and $2.5 \mathrm{GHz}$ bands, which seeks to increase service penetration in rural and remote areas (and thus remove the obstacle of the lacking commercial interest of these areas), aims to expand the economic facility and social opportunity of the individuals who live there. Thus, development would occur.

Increasing competition by dividing the tendering object into radio frequency sub-bands would remove barriers to the entry of new companies into the market and contribute to economic facilities, although from an entrepreneurial perspective. In the U.S., competition has been promoted as the proper means to organize the telecommunications sector, while reflecting the new technological realities and opportunities. According to Teece, this model is the only possible means to facilitate the necessary investment in the telecommunications infrastructure. However, the regulatory approval of the model in the U.S. has been slow, which has decreased opportunity costs and the ability to compete globally. For Teece, the solution would be to remove the entry barrier everywhere in addition to implementing regulatory neutrality. ${ }^{57}$

From an economic perspective, these public policy instruments in the search for universal access and competition aim to correct the so-called "market failures", each in one aspect. Market failures are the failure of real-world markets in meeting the standards of the imaginary market, which is referred to as perfect. This perfect market is characterized by atomicity, whereby each economic agent acts as if the price were fixed (i.e., no buyer or seller is strong enough to exert a significant influence on prices); by homogeneity, whereby the product is homogeneous (i.e., it has the same meaning for everyone involved and should be identifiable in the absence of the seller); by fluidity, which means that buyers and sellers are free to enter or leave the market; and by transparency, whereby economic agents have perfect knowledge of the quantity, quality and price of the offered products. In essence, these failures would be ubiquitous externalities, public goods, imperfect competition and inadequate information. ${ }^{58}$

56 SEN, Amartya. Desenvolvimento como liberdade. São Paulo: Companhia das Letras, 2000. p. 17-25.

57 TEECE, David J. Telecommunications in Transition: Unbundling, Reintegration, and Competition. Michigan Telecommunications and Technology Law Review, v. 1:47, 1999. Disponível em: <http://www.mttlr.org/ volone/teece.pdf>. Acesso em: 05 nov. 2014.

58 Aqui, os atuores citaram o artigo "The use of knowledge in society" de Frederich A. von Hayek. MITCHELL, William C.; SIMMONS, Randy T. Para além da política: mercados, bem-estar social e o fracasso da burocracia. Rio de Janeiro: Topbooks, 2003. p. 64. 
These failures would create inequities in the distribution of wealth, creating inequality. A plausible response to this phenomenon would be public policy. A well-designed state action in this regard would directly benefit the end users of the service (telecommunications consumers) because it would create genuine competition and not additional different prices based on market distortions and produced by random "patchwork." 59 However, several criticisms can be made. For example, neoliberal theorists argue that prices coordinate human activity, and incidentally, the market coordinates better than politics. The markets would be decentralized processes that guide human activity. ${ }^{60}$ Because they are inefficient, policy instruments, such as those used in the telecommunications sector, would simply distort the normal course of activity. Certain researchers go beyond this position to address a more subjective aspect. Friedman distinguishes three types of equality: equality before God, equality of opportunity and equality of outcome. The first concerns the purposes each person possessed at birth, including inherent inequalities that should not be changed by law or another instrument. The second would be the correction of inequalities so that everyone has the same status before the law without the arbitrary obstacles, e.g., skin color, religion or gender, that prevent individuals from pursuing success based on talent. Finally, the equality of outcome aims to achieve a final "equity" between individuals, regardless of the means used to that end. The author strongly criticizes this latter type of equality when sought by governments because it produces the opposite effect, i.e., less equality because the employment of productive labor forces ends up in the hands of individuals with the power to promote their own interests and removes the worker's incentive to produce. ${ }^{61}$ However, public policy on $4 \mathrm{G}$ mobile technology would not seek equality of outcome but equality of opportunity by offering individuals the possibility to purchase the service by themselves and develop their capabilities. Nevertheless, Friedman continues to oppose policies that seek the removal of inequalities by limiting the free market and states that each time that there is no intervention, the "rabble" (we believe that Friedman is referring to individuals without resources) reached levels of life "never dreamed before" because the great achievements of capitalism have always resulted in benefits for the common man. ${ }^{62}$ On the contrary, this claim completely discredits the instruments of public policy, such as cross-subsidies.

\footnotetext{
59 MARASHLIAN, Jonathan S.; HANKINS, Jacqueline R.; MCREYNOLDS, Linda. The Mis-Administration and Misadventures of the Universal Service Fund: A Study in the Importance of the Administrative Procedure Act to Government Agency Rulemaking, 19 CommLaw Conspectus 393 (2011). Disponível em: <http://commlaw. cua.edu/res/docs/06-v19-2-Marashlian-USF-Final.pdf>.

60 MITCHELL, William C.; SIMMONS, Randy T. Para além da política: mercados, bem-estar social e o fracasso da burocracia. Rio de Janeiro: Topbooks, 2003. p. 64.

61 FRIEDMAN, Milton; FIREDMAN, Rose. Liberdade de escolher. o novo liberalismo econômico. Rio de Janeiro: Record, 1980. p. 134-145.

62 FRIEDMAN, Milton; FIREDMAN, Rose. Liberdade de escolher. o novo liberalismo econômico. Rio de Janeiro: Record, 1980. p. 151.
} 
Again from the economic perspective, generally, Furtado begins by observing that development is commonly defined as the increase in the quantity of goods and services during a particular period for a particular community and that quantitative elements are linked to the price system. Next, he criticizes this concept because cultural factors also influence the formation of prices in addition to other matters related to income distribution and market imperfections. For Furtado, development must be linked to the increased flow of social income, whose growth is only possible with the increase in productive capacity. This productive capacity is derived from the transformation of surplus production (gross output minus the necessities of life for everyone linked to production) accumulated by certain minority groups. ${ }^{63}$ In the case of an industrial society, such as present-day society, the accumulation of surplus is in the hands of the businesspeople who reincorporate it into the production process through new techniques, which generates internal market expansion without the need to search for new markets. ${ }^{64}$ Thus, would it not be appropriate to ask whether the expansion of the $4 G$ service to new users through new techniques could not generate increased domestic market and entrepreneurial gains, which would increase productivity and therefore development?

In another perspective, Salomão Filho states that we cannot use a purely economic idea of development because such an idea is only based on efficient outcomes and does not indicate the direction in which the process must occur. This role should be assigned to the law, whose function is essentially linked to the fundamental values of social organization. ${ }^{65}$ This researcher states that underdeveloped economies require the forced diffusion of economic knowledge to develop because excessive concentration creates allocative inefficiencies, which should be the regulatory focus of the modern state. Therefore, the pursuit of the forced diffusion of economic knowledge would be the legal conception of development.

Based on this idea, Salomão Filho elects three guiding principles of the development effort, which would enable society to choose between the options listed in the principles of economic order inscribed under Article 170 of the Federal Constitution. The first principle would be the redistributive principle (artigo 170, VII, Constituição Federal), which would expand the consumption by society. This expansion would result in the inclusion in the economical choice process and the elimination of allocative efficiencies in economic knowledge concentration because the database on

63 FURTADO, Celso. Desenvolvimento e subdesenvolvimento. 5. ed. Rio de Janeiro: Contraponto, 2009. p. 105-111.

64 FURTADO, Celso. Desenvolvimento e subdesenvolvimento. 5. ed. Rio de Janeiro: Contraponto, 2009. p. 135-137.

65 About that relation between Law, State and the fundamental values of social organization, see: RODRÍGUEZ-ARANA MUÑOZ, Jaime. Caraterización constitucional de la ética pública (Especial referencia al marco constitucional español). Revista de Investigações Constitucionais, Curitiba, v. 1, n. 1, p. 67-80, jan./abr. 2014. 
individual preferences would be enlarged. The second principle would be the principle of the dilution of economic power centers (artigo 170, incisos IV e V, da Constituição Federal). According to this principle, competition should be a fundamental guaranteed value because competition increases freedom of choice and consumer information. Additionally, there should be greater involvement of social groups in the process of drafting regulations. Finally, there is the principle of cooperation (artigo 170, incisos IV e V, da Constituição Federal). This principle's goal would be the reduction of strictly individualistic choices at the expense of social choices, whereby the lack of cooperation should be viewed as an informational problem that is not linked to human nature. If economic agents had adequate information, the collective decision would be the most efficient choice (game theory). Cooperative solutions require an environment with a small number of agents with adequate shared information and continuity of the economic relationship. The problem is that reality does not allow this environment, with globalization having an important role in the dysfunction. The solution would be the strengthening of institutions and values to induce cooperativism, with the creation of an enabling environment through law. ${ }^{66}$

Starting from this concept, we clearly envision the developmental scope of the licensing of radio frequency spectra for $4 G$ technology in the pursuit of the forced diffusion of economic knowledge through the implementation of (i) the redistributive principle, which can be achieved by assigning the expansion of $4 G$ service in rural areas to the companies that win the auction, and (ii) the principle of the dilution of economic power centers, which can be realized by increasing competition. Both principles can be observed in the division of the spectrum into sub-bands and lots and in the mandatory waiver of the $3 G$ spectrum by winning companies in the same geographical region.

Therefore, after addressing several answers regarding to the question of whether universal access and competition of $4 G$ mobile technology used to providing access through wireless networks would be able to generate development, we concluded, not definitively, that yes, they would be able either by seeking to enforce the constitutional principles and social rights or by allowing the individuals to develop their skills by themselves, either by generating expansion of the internal market, or by seeking the forced diffusion of economic knowledge.

In this context, the effectiveness of public services, which are mandatory for development, is necessarily linked to the regulatory activity of the state, which organizes economic activity by intervening through the granting of public services to private persons and regulating their use or by exercising police power by enacting rules and supervising. ${ }^{67}$ Rister affirms this necessary regulatory facet of development.

66 SALOMÃO FILHO, C. (Coord.). Regulação e desenvolvimento. São Paulo: Malheiros, 2002. p. 37-41.
67 SALOMÃO FILHO, C. Regulação da atividade econômica. 2. ed. São Paulo: Malheiros, 2008. p. 21. 
She emphasizes that the establishment of standards for each economic sector with such scope generates predictability for the agent, who can act more confidently. Additionally, Rister states that although there is no consensus regarding economic factors for development, the legal system has the power to improve institutions and establish a regulatory model for this purpose. ${ }^{68}$

Thus, we attempt to answer the second question (stated earlier): Could public policy requirements for the sector (with respect to the invitation to tender) based on government regulation in the pursuit of development generate universal access and competition?

As stated in Section B.1, expanding the use of PCS in mobile technologies is only possible by expanding the GSM network, which is the mobile network infrastructure that provides the user with service access (the so-called "last mile" or local loop). That is, for universal access, the expansion of the GSM network is required. As demonstrated by a survey conducted by Pena, Abdalla Junior and Pereira Filho, ${ }^{69}$ through the $3 G$ technology invitation to tender, which accomplished the same goal of universal access established in the $4 G$ technology invitation to tender (joint tendering involving rural areas), there has been progress in the expansion of $3 G$ technology for PMS across the country. Nevertheless, the service has not yet reached several less populated regions. Evidence of service expansion with compulsory universal access in the diffusion of mobile telecommunications can also be found in Central and Eastern Europe. However, numerous controversies remain regarding the use of cross-subsidies for the development of the sector, as described in connection with international experiences.

No evidence of effectiveness was found regarding the promotion of competition through mandatory waiving of existing licenses and the division of the radio frequencies into a larger number of sub-bands. Most likely, these mechanisms did not achieve their goals because the winning companies were Claro, Vivo, Tim and $\mathrm{O} i$, which dominate the market. However, as previously described, after the regulation of the sector, there was an increase in mobile telephony competition because the concessionaires disputed the market with groups formed from the duopoly established for CMS, which quickly expanded the service.

Thus, we have found strong evidence that the public policy requirements for the sector (expressed in the invitation to tender) in the pursuit of development can generate universal access to the service. Regarding competition, we could not establish a stronger proposition because the only evidence of effectiveness occurred at the time of tendering, not during the development of the market.

\footnotetext{
68 RISTER, Carla Abrantkoski. Direito ao desenvolvimento: antecedentes, significados e consequências. Rio de Janeiro: Renovar, 2007. p. 7.

69 PENA, André Garcia; ABDALLA JÚNIOR, Humberto; PEREIRA FILHO, José Leite. A banda larga e o cenário brasileiro das telecomunicações. Revista de Direito, Estado e Telecomunicações, v. 4, n. 1, p. 237-302, 2012. p. 243-258.
} 


\section{Conclusion}

The current normative framework for broadband is inserted in a legal system for the telecommunications sector created to stimulate competition and universal access in the face of new demands for the regulation of competitive public services. These demands changed several parameters of traditional public services in a context of redefining the role of the state in the 1990s and require that instruments are adopted through public policies that aim at such stimuli.

Both pillars of the legal system are connected to a broader vision of how the state should act in the economy to foster development. It was concluded that universal access and competition with respect to the $4 G$ mobile technology used to provide access through wireless networks would be able to generate development. as they would realize constitutional principles and social rights would be recognized, which would enable individuals to develop their capabilities, expand the domestic market and promote the forced diffusion of economic knowledge.

Based on these requirements and several decrees and resolutions supported by LGT and the Federal Constitution, ANATEL issued the Invitation to Tender No. 004/2012/PVCP/SPV with three public policy instruments. Two instruments aimed to increase competition: the obligation to waive existing licenses by the winning companies in the same territory and the division of the tendered radio frequencies into sub-bands. The sub-bands were grouped into lots for auction. One aim was universal access through cross-subsidization, which was incorporated into the joint tendering of the $450 \mathrm{MHz}$ and $2.5 \mathrm{GHz}$ bands. The first band was designated for rural areas.

Regarding the latter, expanding the use of CMS by expanding its GSM network would provide universal access. This goal could be achieved because of experience with the previous technology $(3 G)$ on the national level, international experience with the forced realization of the principle and the use of cross-subsidization. This achievement demonstrates the effectiveness of this public policy instrument.

The same cannot be stated regarding the increase in competition. The tender winners were Claro, Vivo, Tim and Oi. These companies largely dominate the market. These companies are rapidly expanding service. However, there is no consistent evidence that their competition benefits the consumer while properly developing the market, perhaps because the process remains at an early stage.

\section{O caso da tecnologia $4 \mathrm{G}$ na legislação brasileira de telecomunicações}

Resumo: A constante e rápida evolução do setor de telecomunicações imprimiu a necessidade de inserção de mecanismos em sua regulamentação para que fossem atingidos os objetivos voltados ao desenvolvimento delineados pela Constituição Federal brasileira. Neste sentido, elaborou-se uma política pública setorial com vistas ao incremento da universalização e à ampliação da concorrência. A licitação das autorizações para operação da denominada tecnologia 4G, dentro deste quadro, buscou, de um lado, 
ampliar a universalização por meio do subsídio cruzado consubstanciado na licitação conjunta de faixas de frequência em áreas rurais e, por outro, aumentar a concorrência por meio da obrigatoriedade de renúncia às autorizações já existentes em tecnologias antigas, que irão coexistir com a nova. Para averiguar se tais expedientes podem alcançar o objetivo proposto, o presente artigo, utilizando-se dos métodos descritivo, indutivo e interdisciplinar, estabelece, primeiramente, o atual quadro regulatório do setor e aspectos técnicos da nova banda larga, para, posteriormente, comparar os instrumentos empregados com experiências semelhantes anteriores brasileiras e internacionais. Por fim, chega-se à conclusão de que a universalização pode ser alcançada com tais instrumentos, o que não ocorre com a concorrência.

Palavras-chave: Telecomunicações. Universalização. Concorrência. Desenvolvimento. Empresa.

\section{References}

AGUILAR VALDEZ, Oscar Rafael. Reflexiones sobre la titularidad y el título de intervención estatal en las infraestructuras públicas. Revista de Direito Econômico e Socioambiental, Curitiba, v. 6, n. 1, p. 114-139, jan./jun. 2015.

BACELLAR FILHO, Romeu Felipe. Concessão, permissão e autorização de serviço público. In: CARDOZO, José Eduardo Martins; QUEIROZ, João Eduardo Lopes; DOS SANTOS, Márcia Walquriria Batista (Coord.). Direito Administrativo Econômico. São Paulo: Atlas, 2011.

BALBíN, Carlos F. Un Derecho Administrativo para la inclusión social. A\&C - Revista de Direito Administrativo \& Constitucional, Belo Horizonte, v. 14, n. 58, p. 105-131, 2014.

BARRAL, Welber. Desenvolvimento e sistema jurídico: a busca de um modelo teórico. In: BARRAL, Welber; PIMENTEL, Luiz Otávio (Org.). Teoria jurídica e desenvolvimento. Florianópolis: Fundação Boiteux, 2006.

BERCOVICI, Gilberto. Revolution trough Constitution: the Brazilian's directive Constitution debate. Revista de Investigações Constitucionais, Curitiba, v. 1, n. 1, p. 7-18, jan./abr. 2014.

CÂMARA, Jacinto Arruda. Tarifa nas concessões. São Paulo: Malheiros, 2009.

COELHO, Rafael Isaac de Almeida. Licitação sustentável em concessão de energias renováveis. Revista de Direito Econômico e Socioambiental, Curitiba, v. 5, n. 2, p. 79-96, jul./dez. 2014.

DAVIDSON, Charles M.; SANTORELLI, Michael J. Seizing the Mobile Moment: Spectrum Allocation Policy for the Wireless Broadband Century. CommLaw Conspectus Journal of Communications Law and Policy. Washington: Columbus School of Law (Catholic University of America), v. 19, Issue 1, 2010. Disponível em: <http://commlaw.cua.edu/res/docs/articles/v19/19-1/05-v19-1-REVISEDDavidsonSantorelli-Final.pdf>. Acesso em: 10 maio 2014.

DEGNAN, Peter M.; MCLAREN, Scott A.; TENNANT, Michael. The telecommunications act of 1996: $\S 704$ of the act and protections afforded the telecommunications provider in the facilities siting context. Michigan Telecommunications and Technology Law Review, v. 3:1, 1999. Disponível em: <http://www.mttlr.org/volthree/mclaren.pdf>. Acesso em: 11 maio 2014.

DELPIAZZO, Carlos E. Centralidad del administrado en el actual Derecho Administrativo: impactos del Estado Constitucional de Derecho. Revista de Investigações Constitucionais, Curitiba, v. 1, n. 3, p. 7-32, set./dez. 2014.

DEMO, Pedro. Metodologia do conhecimento científico. São Paulo: Atlas, 2000.

DI PIETRO, Maria Sylvia Zanella (Org.). Parcerias na Administração Pública - Concessão, Permissão, Franquia, Terceirização e outras formas. 4. ed. São Paulo: Atlas, 2002.

DI PIETRO, Maria Sylvia Zanella. Direito, Estado e Telecomunicações: fronteiras institucionais regulatórias. [Editorial]. Revista de Direito, Estado e Telecomunicações, v. 5, n. 1, p. 1-28, 2013. 
ESTEVES, Henrique Perez. Ativismo normativo na aplicação constitucional do desenvolvimento sustentável. Revista de Direito Econômico e Socioambiental, Curitiba, v. 5, n. 1, p. 91-109, jan./ jun. 2014.

FARACO, Alexandre Ditzel. Capítulo 2: Regulação das telecomunicações: entre concorrência e universalização. In: SHAPIRO, Mário Gomes (Coord.). Direito e Economia na Regulação Setorial. São Paulo: Saraiva, 2010.

FAULHABER, Gerald R. Cross-Subsidization: Pricing in Public Enterprises. The American Economic Review, v. 65, n. 5, 1975, p. 966-977. Nashville: American Economic Association. Disponível em: <http://www.jstor.org/stable/1806633>. Acesso em: 26 jul. 2013.

FINGER, Ana Claudia; QUETES, Regeane Bransin. Licitações e contratos administrativos sustentáveis como um instrumento de concretização da supremacia do interesse público. A\&C-Revista de Direito Administrativo \& Constitucional, Belo Horizonte, v. 14, n. 57, p. 33-60, 2014.

FRIEDMAN, Milton; FRIEDMAN, Rose. Liberdade de escolher. o novo liberalismo econômico. Rio de Janeiro: Record, 1980.

FURTADO, Celso. Desenvolvimento e subdesenvolvimento. 5. ed. Rio de Janeiro: Contraponto, 2009.

GABARDO, Emerson. Eficiência e legitimidade do Estado. Barueri: Manole, 2003.

GIL, Antônio Carlos. Como elaborar projetos de pesquisa. São Paulo: Atlas, 2007.

GRAU, Eros Roberto. A Ordem Econômica na Constituição de 1988. 9. ed. São Paulo: Malheiros, 2004.

GROTTI, Dinorá Adelaide Musetti. Teoria dos serviços públicos e sua transformação. In: SUNDFELD, Carlos Ari (Coord.). Direito Administrativo Econômico. São Paulo: Malheiros, 2006.

GRUBER, Harald. Competition and innovation: the diffusion of mobile telecommunications in Central and Eastern Europe. Information Economics and Policy, n. 13, Elsevier, mar. 2000. Disponível em: <http:// ssrn.com/abstract=191989 or http://dx.doi.org/10.2139/ssrn.191989>. Acesso em: 26 jul. 2013.

HACHEM, Daniel Wunder. A noção constitucional de desenvolvimento para além do viés econômico: reflexos sobre algumas tendências do Direito Público brasileiro. A\&C - Revista de Direito Administrativo \& Constitucional, Belo Horizonte, ano 13, n. 53, p. 133-168, jul./set. 2013.

HACHEM, Daniel Wunder. Direito fundamental ao serviço público adequado e capacidade econômica do cidadão: repensando a universalidade do acesso à luz da igualdade material. $A \& C-R e v i s t a ~ d e$ Direito Administrativo \& Constitucional, Belo Horizonte, ano 14, n. 55, p. 123-158, jan./mar. 2014.

HACHEM, Daniel Wunder. Mínimo existencial y derechos económicos y sociales: distinciones y puntos de contacto a la luz de la doctrina y jurisprudencia brasileñas. Revista Eurolatinoamericana de Derecho Administrativo, Santa Fe, v. 1, n. 1, p. 93-138, ene./jun. 2014.

KASERMAN, David L.; MAYO, John W.; FLYNN, Joseph E. Cross-subsidization in telecommunications: Beyond the universal service fairy tale. Journal of Regulatory Economics, v. 2, p. 231-249, set. 1990.

MAJUMDAR, Sumit K.; CHANG, Hsihui. Regulations and Technology Diffusion: Cross Subsidies and Digital Infrastructure Creation. Annals of Public and Cooperative Economics, 84, p. 159-178, 2013.

MARASHLIAN, Jonathan S.; HANKINS, Jacqueline R.; MCREYNOLDS, Linda. The mis-administration and misadventures of the universal service fund: a study in the importance of the administrative procedure act to government agency rulemaking. CommLaw Conspectus Journal of Communications Law and Policy. Washington: Columbus School of Law (Catholic University of America), v. 19, Issue 2, 2011. Disponível em: <http://commlaw.cua.edu/res/docs/06-v19-2-Marashlian-USF-Final.pdf>. Acesso em: 10 maio 2014.

MARQUES NETO, Floriano Azevedo. Direito das telecomunicações e ANATEL. In: SUNDFELD, Carlos Ari (Coord.). Direito Administrativo Econômico. São Paulo: Malheiros, 2006. 
MARTíNEZ, Augusto Durán. Estado Constitucional de Derecho y Servicios Públicos. A\&C - Revista de Direito Administrativo \& Constitucional, Belo Horizonte, v. 15, n. 60, p. 39-59, 2015.

MASSIMINO, Leonardo F. La intervención estatal, la regulación económica y el poder de policía: análisis y tendências. Revista de Direito Econômico e Socioambiental, Curitiba, v. 6, n. 1, p. 36-63, jan./jun. 2015.

MITCHELL, William C.; SIMMONS, Randy T. Para além da política: mercados, bem-estar social e o fracasso da burocracia. Rio de Janeiro: Topbooks, 2003.

MOURA, Emerson Affonso da Costa. Estado Gerencial, Regulação Econômica e Serviços Públicos: o Papel das Agências na Promoção do Desenvolvimento. A\&C-Revista de Direito Administrativo \& Constitucional, Belo Horizonte, v. 14, n. 57, p. 193-218, 2014.

NOBRE JÚNIOR, Edilson Pereira. Uma ideia de Constituição. Revista de Investigações Constitucionais, Curitiba, v. 1, n. 1, p. 111-145, jan./abr. 2014. p. 138-139.

NOHARA, Irene Patrícia. Desafios jurídicos das Parcerias Público-Privadas (PPPs) e desenvolvimento nacional sustentável. Revista de Direito Econômico e Socioambiental, Curitiba, v. 5, n. 2, p. 184-203, jul./dez. 2014. p. 187-190.

NUNES, Luciana Gonçalves. Finalidades e limitações da intervenção do Estado na economia sob a ótica da Constituição da República de 1988. Revista de Direito Econômico e Socioambiental, Curitiba, v. 2 , n. 1, p. 83-99, jan./jun. 2011.

NUSDEO, Fábio. Curso de Economia - Introdução ao Direito econômico. 3. ed. São Paulo: Revista dos Tribunais, 2001.

PENA, André Garcia; ABDALLA JÚNIOR, Humberto; PEREIRA FILHO, José Leite. A banda larga e o cenário brasileiro das telecomunicações. Revista de Direito, Estado e Telecomunicações, v. 4, n. 1, p. 237-302, 2012.

PERLINGEIRO, Ricardo. Recognizing the public right to healthcare: the approach of Brazilian courts. Revista de Investigações Constitucionais, Curitiba, v. 1, n. 1, p. 19-37, jan./abr. 2014.

PLACHA, Gabriel. Os impactos e as perspectivas da regulação estatal sobre as atividades econômicas. Revista de Direito Econômico e Socioambiental, Curitiba, v. 1, n. 2, p. 251-270, jul./dez. 2010.

RESENDE, Augusto César Leite de; GABARDO, Emerson. A atividade administrativa de fomento na gestão integrada de resíduos sólidos em perspectiva com o desenvolvimento sustentável. $A \& C-R e v i s t a$ de Direito Administrativo \& Constitucional, Belo Horizonte, ano 13, n. 53, p. 105-131, jul./set. 2013.

RISTER, Carla Abrantkoski. Direito ao desenvolvimento: antecedentes, significados e conseqüências. Rio de Janeiro: Renovar, 2007.

RODRÍGUEZ-ARANA MUÑOZ, Jaime. Caraterización constitucional de la ética pública (Especial referencia al marco constitucional español). Revista de Investigações Constitucionais, Curitiba, v. 1, n. 1, p. 67-80, jan./abr. 2014.

SALOMÃO FILHO, Calixto (Coord.). Regulação e desenvolvimento. São Paulo: Malheiros, 2002.

SALOMÃO FILHO, Calixto. Regulação da atividade econômica. 2. ed. São Paulo: Malheiros, 2008.

SANT'ANA, Diogo. Capítulo 9: Conjuntura da regulação no Brasil: conflitos e convergências. In: Direito Econômico Regulatório. São Paulo: Saraiva, 2010.

SEN, Amartya. Desenvolvimento como liberdade. São Paulo: Companhia das Letras, 2000.

SHIRATO, Vitor Rhein. A regulação dos serviços públicos como instrumento para o desenvolvimento. Interesse Público - IP, Belo Horizonte, ano 7, n. 30, mar./abr. 2005. 
SOARES, Inês Virgínia Prado. Direito ao desenvolvimento e Justiça de transição - conexões e alguns dilemas. In: PIOVESAN, Flávia; SOARES, Inês Virgínia Prado (Coord.). Direito ao Desenvolvimento. Belo Horizonte: Fórum, 2010.

TEECE, David J. Telecommunications in transition: unbundling, reintegration, and competition. Michigan Telecommunications and Technology Law Review, v. 1:47, 1999. Disponível em: <http://www.mttlr. org/volone/teece.pdf>. Acesso em: 11 maio 2014.

VALLE, Vanice Regina Lírio do. Judicial adjudication in housing rights in Brazil and Colombia: a comparative perspective. Revista de Investigações Constitucionais, Curitiba, v. 1, n. 2, p. 67-102, maio/ago. 2014.

VIEIRA, Oscar Vilhena; DIMOULIS, Dimitri. Constituição e desenvolvimento. In: LIMA, Maria Lúcia L. M. Padua (Coord.). Agenda Contemporânea - Direito e Economia - 30 anos de Brasil. t. 1, Série GVLaw. São Paulo: Saraiva, 2012.

Informação bibliográfica deste texto, conforme a NBR 6023:2002 da Associação Brasileira de Normas Técnicas (ABNT):

MORETTINI, Felipe Tadeu Ribeiro; GABARDO, Emerson. The Case of 4G Technology in the Brazilian Telecommunication Law. A\&C - Revista de Direito Administrativo \& Constitucional, Belo Horizonte, ano 15, n. 61, p. 13-41, jul./set. 2015.

Recebido em: 30.05.2015

Aprovado em: 05.07.2015 